\title{
Botrytis Rot on Litchi chinensis, a New Record from Himachal Pradesh, India
}

\section{Sunita Chandel and Praneet Chauhan*}

Department of Plant Pathology, Dr. Y S Parmar University of Horticulture and Forestry, Nauni, Solan 173230, H.P., India

*Corresponding author

A B S T R A C T

\section{Keywords \\ Botrytis, fungal mass, Litchi chinensis}

Article Info

Accepted:

17 June 2017

Available Online:

10 August 2017
Botrytis rot was observed on fruits of Litchi (Litchi chinensis Sonn.) from Himachal Pradesh, India is a new host record. Symptoms of the disease appeared in the form of grayish fungal mass on the stem end of the litchi fruit with around 20.5 per cent severity.

\section{Introduction}

Litchi (Litchi chinensis Sonn.) is a tropical and subtropical fruit of high commercial value for its white, translucent aril and attractive red colour.

The major limitation in litchi marketing is the rapid loss of red colour and the decay of fruit after harvest (Jiang et al., 2003).

During the year 2016, a survey was conducted in and around the fruit vendors of Solan, Himachal Pradesh and it was seen that the grayish fungal mass has entirely covered the stem end of the litchi fruit.

Small spots appeared on the surface of mature fruits. Grey mycelia and conidiophores developed on the diseased fruits.

The infected fruit were analysed under a microscope for the presence of rotting symptoms. The microscopic observations were undertaken for morphological characteristics of mycelia, shape of conidia and conidiophores. It was revealed by microscopic analysis that the fungus belongs to genus Botrytis. To isolate the causal agent, conidia and conidiophores were scraped aseptically from the internal tissues, suspended in sterile water, and streaked onto the surface of potato dextrose agar (Fig. 1).

Single-hyphal tips were transferred on PDA and the isolated fungus was identified as Botrytis cinerea Pers. (Fr.) on the basis of its morphological characteristics. Conidia were single celled, lemon shaped, colorless to a light color, and 4.4 to $15.0 \times 7.0$ to $10.0 \mu \mathrm{m}$.

The causal agent was identified as $B$. cinerea when it was observed under compound microscope (Fig. 2). 
Fig.1 Pure culture of Botrytis cinerea

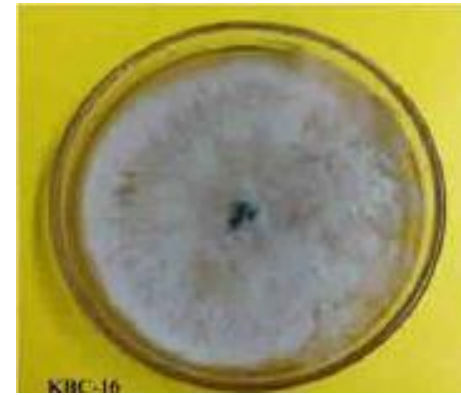

Fig.2 Conidia and conidiophores of B. cinerea

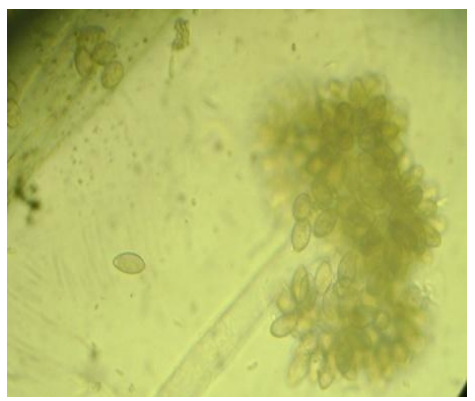

Fig.3 Pathogenicity test on Litchi fruits

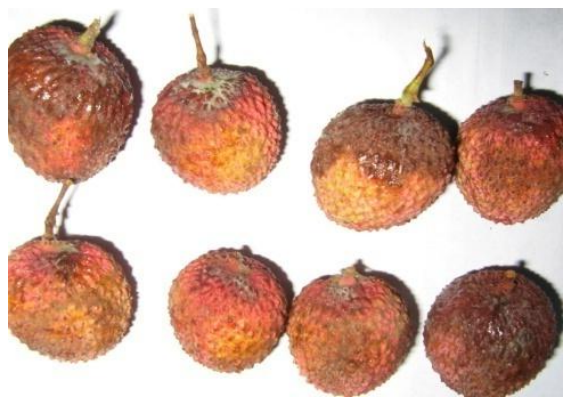

Pathogenicity tests were carried out on healthy litchi fruit (Fig. 3). After the surface of the fruits was disinfected with $5 \%$ sodium hypochlorite, a conidial suspension of $10^{5}$ conidia/ml was sprayed on eight litchi fruits under bell jar were covered with and incubated at $25^{\circ} \mathrm{C}$ in an incubator. The first symptom appeared on the litchi with mycelia and conidia after four days of inoculation and rapidly spread to nearby fruits. The causal pathogen was re-isolated from the lesions to confirm Koch's postulates. On the basis of mycological characteristics and pathogenicity testing in host plants, the fungus was identified as $B$. cinerea Persoon: Fries (Ellis and Waller, 1974). Previously, B. cinerea has been reported from Korea and Taiwan on other hosts such as blueberry and sweet pepper (Kwon et al., 2011; Huang and Sung, 2017).To the best of our knowledge, this is the first report of rot on litchi caused by $B$. cinerea in Himachal Pradesh, India. 


\section{References}

Jiang Y M, Yao L, Lichter A and Li J. 2003. Postharvest biology and technology of litchi fruit. Food, Agriculture and Environment, 2, 76-81.

Ellis M B, Waller J M. 1974. Sclerotinia fuckeliana (conidial state: Botrytis cinerea). CMI descriptions of pathogenic fungi and bacteria, No. 431. Kew: Commonwealth Mycological
Institute.

Kwon J H, Cheon M G, Choi O and Kim J.2011. First report of Botrytis cinerea as a postharvest pathogen of Blueberry in Korea. Mycobiology 39(1): 52-53

Huang C J and Sung I H. 2017. First report of Botrytis cinerea causing postharvest fruit decay of goat-horn sweet pepper in Taiwan. Journal of Plant Pathology 99(2).

\section{How to cite this article:}

Sunita Chandel and Praneet Chauhan. 2017. Botrytis Rot on Litchi Chinensis, a New Record from Himachal Pradesh, India. Int.J.Curr.Microbiol.App.Sci. 6(8): 1315-1317. doi: https://doi.org/10.20546/ijcmas.2017.608.159 